\title{
Fostering Entrepreneurship, Creativity and Innovation in Cities
}

\author{
Elzo Alves Aranha ${ }^{1}$, Neuza Abbud Prado Garcia ${ }^{2}$, Paulo Henrique Dos Santos ${ }^{1}$ \\ ${ }^{1}$ Federal University of Itajubá, Brazil \\ ${ }^{2}$ University of Sao Paulo, Brazil \\ Correspondence: Elzo Alves Aranha, Federal University of Itajubá, Brazil.
}

Received: February 11, 2017

Accepted: March 10, 2017

Online Published: March 23, 2017

doi:10.5539/ibr.v10n4p92

URL: https://doi.org/10.5539/ibr.v10n4p92

\begin{abstract}
The aim of this study is to develop a new tool to foster entrepreneurship, creativity and innovation in cities. The tool consists of transformative dimensions, able to synthesize, assemble and embrace the notions of entrepreneurial city, creative and innovative. Then it seeks to illustrate the operation of the city model proposed taking into account 51 Cities Master Plans in Brazil. The study is exploratory and adopts a reflexive methodology. The main innovative result is the entrepreneurial city model tool which meets five essential transformative dimensions: value proposition, customers, value configurations, strategic partnerships and revenue model. The entrepreneurial city model tool proposed aims to increase the dynamics understanding of the procedural flow in the city context, from the entrepreneurial activity perspective. This process flows dynamics can be expressed in the city, for example, in the planning, implementation and actions monitoring, programs, projects and public policies directed to notions of entrepreneurial city, creative and innovative. The innovative results of this research have several practical implications, among which are: (1) public management in the city; (2) public policy makers; (3) researchers and scholars; (4) human resource professionals.
\end{abstract}

Keywords: entrepreneurship, creativity, innovation, city model, city management

\section{Introduction}

Although the term city model has been adopted in the international academic literature in order to reference 3D city (Žiūrienè, Mešliūtè and Makutėnienė 2006; Smart, Quinn and Jones 2011; Yasumoto et al 2011; Cappelle et al 2012; Jahnke, Krisp and Kumke 2011; Sahin et al 2012), little attention has been devoted by researchers in order to associate it with the term business model, and to tools which help the design, regeneration, planning, implementation and monitoring of public management of the city, towards an entrepreneurial society (Gibb 2002). Another early finding identified in the international academic literature is how little attention is being paid by the researchers, to associate or connect the city model term with entrepreneurial city, creative and innovative (Chapin 2002; Jessop and Sum 2000; A. Andersson and D. Andersson 2015; Grodach 2013; Hospers and Pen 2008; Marceau 2008; Fang et al 2014; Inkinen 2015; Evans 2009; Bakici, Almirall and Wareham 2013; Doran and Daniel 2014). The initial review of the international academic literature indicated that the term city model does not provide any information that makes it possible to analyze it as a tool consisting of elements which guide the design and implementation of projects, programs and public policies related to the entrepreneurial city notions, creative and innovative.

Therefore, if the term city model does not provide any information that makes it possible to analyze it as a reference model related to the entrepreneurial city, creative and innovative notions, there would be an incongruity in relation to the conceptual assertions of this tripod (entrepreneurship, creativity and innovation). The incongruity refers to the absence of abstraction instance in the tripod (entrepreneurship, creativity and innovation). The instance would be the composition of cognitive elaborations involving two key issues: (1) reasoning and sensitivity to ensure progress for novelty; (2) the subject actions involving such conditions.

Considering the reality or real, according to conceptual standards, it is thought in the human being, inserted in this living context, taking as reference the preservation of minimal living conditions regarding to respect and the being dignity. Because, by influences, tensions and faced changes in the context of micro to macro society (economic, political-legal, socio-cultural, technological, demographic, environmental), human being life is threatened. In this direction, to overcome, reduce or eliminate incongruity it is necessary to broaden the power of understanding of the term city model. However, if there are considerations that the historic building is made 
every time in the disruptions interweaving and reconstructions, it'll be possible to reflect on a representative rapport of a material-symbolic process. The rapport refers the construction of a reference in order to guide the term city model in a dynamic that involves the context of this construction underlying model.

The identified gap in the literature opens a set of questions related to the city management, among which are: (1) Is there any difference or similarity between the entrepreneurial city of notions, creative city and innovative city? (2) What practical implications of the connection between these concepts can provide the design, monitoring and implementation of programs, projects and public policies for cities and the state? (3) In which city design the programs formulators, projects and local or state public policies should pursue to settle the city management from entrepreneurship, creativity and innovation? (4) Which model to be city mapped, aims to increase the understanding of these notions of city, in order to cover its determinant categories? These issues leave the city management field with a lack of tools which can facilitate the understanding of these dynamics in the formulation, monitoring and tracking of these same public policies. It is pointed out in this article that the term city model should encompass the concepts entrepreneurship, creativity and inno vation in a single model analysis, helping to broaden the understanding of the cities regeneration processes, enabling the generation of inferences, information and support tools and assistance to the public administration.

The goal of this article is to develop an entrepreneurial city model tool made of transformative dimensions, able to synthesize, assemble and embrace the notions of entrepreneurial city, creative city and innovative city, as an alternative to the existing city model concept in the literature. Then seeks to illustrate the operation of the entrepreneurial city model tool taking into account the Brazilian City Statute (Brazilian Law) and 51 Brazilian Cities Master Plans.

The paper is structured into six sections. The first section is designed to review the city model state of the art, the individual entrepreneur as agent and entrepreneurial, creative and innovative city notions. The second section outlines the key elements governing the research methods and techniques. The following section proposes the city model transformative dimensions. In the fourth section seeks to provide illustrations of the processing dimensions operation. In the fifth section highlights the contributions, impacts and implications of the research. Finally, the last section is dedicated to the final considerations.

\section{State of the Art}

\subsection{What does the Literature Mention about City Model?}

Gruen and Wang (1998) have adopted the term city model to designate a type of city as a generator of 3D objects topology of the photogrammetry field. The adoption of the city model term for 3D objects expanded and established close links over the past ten years. The main works analyze city model term in four directions: (1) the 3D city model applied to the registration information (Žiūriené, Mešliūtė and Makutėniené 2006); (2) mobile technology with 3D city model (Smart, Quinn and Jones 2011); (3) virtual city model (Yasumoto et al 2011 ; Cappelle et al 2012; Jahnkee, Krisp and Kumke 2011); (4) combination of photogrammetry and 3D laser scanner (Sahin et al 2012). Other studies have proposed empirical tools for architects and planners analyze and predict the flow of traffic to the public transport network (Aschwanden et al 2012) and city traffic model in transport (Pastén et al 2012; Dawood et al 2015).

The flag of the term city model linked to the city management tool has been raised from a study by Abbott (1997), proposing the international city hypothesis. The study of Abbott (1997) suggests that the international city is understood as a city model that starts from the interest of the cities in linking marketing operations worldwide. These marketing operations are characterized as complex systems on a global scale (Abbott 1997). In proposing complex marketing operations on a global scale, the international city of Abbott (1997) acquires a competitive advantage in the opportunity to capture attraction and leadership in the business era. This assists in the implementation of competitive actions in the international city (Abbott 1997).

The sustainable city model Egger (2006), on the other hand, raised the sustainability banner within the city, combined with the network society. According to Egger (2006), the city can be considered sustainable if their structures and operations are presented indivisible on the planet.In the Sustainable city, the development of social, environmental, political and cultural, economic and physical are essential and must be promoting key compounds attributes of public services (Egger 2006).

From 2013, in addition to the continuing work on 3D virtual cities, the academic articles city model have expanded in two other directions, namely: (1) development of new concepts that have collaborated for the cities management and competitiveness; (2) General city models that are grouped various models. The combination between the city model and competitiveness was explored in the Singhal, McGrealb and Berry (2013) work, 
suggesting regeneration and business strategies as path toward a competitive city. Singhal, McGrealb and Berry (2013) also propose a hierarchical methodology for evaluating the cities competitiveness. This proposal, which has been studied in the UK in the begining is based on regeneration and business strategies for urban competitiveness, and later being expanded in five cities in India (Singhal, Mcgreal and Berry 2013).

In the field of general city models there are works about city as a nexus, compact city model and multi-city model. The city as a nexus suggests that the development of the city and the region require a transdisciplinary approach (Jacobs 2016). In this approach, there are the situational factors, namely: (1) governmental action; (2) market factors; (3) societal factors; (4) geo-spatial. All these factors connect activities of human life (Jacobs 2016). The notion of compact city is made up by aspects of urban density, from the 2030 plan for the city of Melbourne, Australia (Chhetri et al 2013). Other initiatives refer to the circular city model (Lin and Wu 2015) and gas emission (Liu et al 2013 ), called multi-city model.

\subsection{The Creative and Innovative Daring and/or Entrepreneurial Attitude}

The entrepreneur is an individual who has an attitude toward cognitive processes engendered by the creation and innovation (Filion 1993). It follows that creativity and innovation are skills and categories that develop in the sphere of the individual entrepreneur. Filion (1993) points out a set of skills which contribute to overcome the new challenges in the organizations, among which we highlight the entrepreneurial vision, entrepreneurial leadership and energy, considered fundamental to human behavior in postmodern organizations (Filion 1993). Called entrepreneur metamodel, the Filion (1993) proposal points out that one of the fundamental characteristics of the individual is vision, that is, the image projected into the future of a product, service, technology, proc ess or project to be developed (Filion 1993). Other features, such as leadership and energy, are developed by the entrepreneur to implement his vision (Filion 1993).

In other words, there is a vast literature in the entrepreneurship field highlighting the issue of entrepreneurship as the bulwark for the building of a more humane and fair society (Gibb 2002; Mok 2005). What is needed is therefore a decoupage to constitute the entrepreneurship as substantivation of a name and may have a representative in its referent. When Schumpeter $(1934,1961)$ states that for the innovation construction will be required the destruction of the old and the creation of the new called creative destruction, it would be in such a direction, with respect to technological developments in the border horizon?

At the same time the authors, emphasize, (Hébert and Link 2006; Hisrich and Peters 2004), in order to meet the demand excess for entrepreneurship education, many institutions are recruiting teachers whose training comes often from the business context instead of the academies. Hébert and Link (2006) tend to emphasize specific problems without any conceptual exercise or historical context. Thus, currently the entrepreneurial vision is focal, involving Economics, Sociology and Management areas (Hébert and Link 2006). Thus, it is asked whether these areas would exhaust the problem and the correct use of the term it is as entrepreneurship or entrepreneurial attitude.

The sphere of the human being has been mentioned by Gibb (2002) emphasizing that the globalization whene ver it emerges raises a number of questions about the individuals and organizations role in the post-modern society. Pointing the pressure occurrence of various kinds upon the individual (individual, personal and organizational), Gibb (2002) emphasizes the importance of entrepreneurial paradigm to overcome these pressures in postmodern society. The entrepreneurial society proposed by Gibb (2002) is based on the new learning paradigm that is the entrepreneurial education. This overcome occurs from the innovation as one of the entrepreneur essential skills (Gibb 2002). In this field, Schumpeter (1934) was one of the first to associate the entrepreneur and the innovation.

Relying on the prerogative that the processes engendered above are de veloped in the individual sphere, it appears that the entrepreneurial behavior, creative and innovative also develop in the group ball. This sphere extends through the interactions and own procedural dynamics of the groups, also presented in the organizations. The entrepreneurial skills of Filion (1993) collaborate to foster innovation and entrepreneurship for the organizations growth. Caldas, Fachin and Fischer (1997) present some proposals in the innovation analysis on organizations, namely: (1) construction of organizational activities from innovation; (2) factors analysis that lead to organizations to innovate; (3) seeking ways to work the innovation in complex organizations. These propositions collaborate in order to work the generated tensions by the difficulty of the organizations to innovate as well as seeking to resolve their problems from the innovation (Caldas, Fachin and Fischer 1997; Hatch 1997).

\subsection{Entrepreneurship, Creativity and Innovation Contributions for a City Model Tool}

Audretsch, Belitski and Desai (2015) state that cities offer possibilities to be studied from the entrepreneurial 
perspective. Over time, the implemented actions in the cities management towards entrepreneurship generate an effect that may result in economic growth and cities development (Audretsch, Belitski and Desai 2015). In this direction, Dannestam (2008) states that the formulations of urban competitiveness strategies are fundamental for the creation of an entrepreneurial city. The formulation of the se strategies, according to Jessop and Sum (2000), occurs from the entrepreneurial attitude of public policy makers, who begin to act as entrepreneurs in the decision making.

According to Chapin (2002), in the entrepreneurial city the development of the private sector is encouraged from programs promoted by the public sector. The establishment of public-private partnerships and innovation bases are essential for the entrepreneurial city development (Chapin 2002). The integration of urban infrastructure, sustainable development, opening new markets as well as redefining the city position as a global agent also show to be essential for the entrepreneurial cities development (Jessop and Sum 2000; Dannestam 2008; Rahman and Fatima 2011; Hackler 2011).

Another aspect in the development of cities is related to creative and cultural activities. According to Costa et al (2007), cultural activities (creative by nature) are one of the key points of the cities' development strategies. Creativity is an important tool for economic growth and innovation of the cities, as well as the generation of knowledge and the adoption of a culture of knowledge (Grodach 2013; Hospers and Pen 2008).

Thus, the creative city proposes the formulation of urban de velopment strategies aimed at economic growth, local development and urban renewal (Costa et al 2007). According to Costa et al (2007), these strategies are developed from the use of creativity and urban de velopment tool. The creative city focuses its development on attracting highly skilled human resources and creative industries, in addition to the use of creativity as economic growth tool (Costa et al 2007; Grodach 2013; Pratt 2010).

According to Shearmur (2012), innovation is the main way that stimulates economic growth. It is in the cities that occur activities which stimulate the national economy, because they are the center of discussions when innovation is addressed in a regional context (Shearmur 2012). Inkinen (2015) states that the innovative city can be designed both from the creation of a contemporary image and developed of the city (branding), as by the technological profile of public and private services available for the population (public and private technological services). The innovative city construction comes from the public branches, which projects the city development from the generation of innovative and technological knowledge (Marceau 2008; Fang et al 2014; Inkinen 2015; Oh et al 2016).

Table 1. Analysis Categories of Entrepreneurship, Creativity and Innovation in Cities

\begin{tabular}{|c|c|c|}
\hline Analysis Area & Author(s) & $\begin{array}{l}\text { Analysis Categories } \\
\end{array}$ \\
\hline \multirow{6}{*}{ Entrepreneurship } & Jessop and Sum (2000) & \multirow{6}{*}{$\begin{array}{c}\text { Entrepreneurial strategies of public agencies } \\
\text { Entrepreneurship as a stimulate agent of economic development } \\
\text { Entrepreneurial strategies of public agencies and partnerships with } \\
\text { the private sector } \\
\text { Entrepreneurship as a comprehension tool of urban activities } \\
\text { Entrepreneurial strategies of public agencies } \\
\text { Innovative strategies to increase the city competitiveness }\end{array}$} \\
\hline & Chapin (2002) & \\
\hline & Doucet (2013) & \\
\hline & $\begin{array}{l}\text { Glaeser, Rosenthal and Strange } \\
\text { (2010) }\end{array}$ & \\
\hline & Rahman and Fatima (2011) & \\
\hline & Dannestam (2008) & \\
\hline \multirow{9}{*}{ Creativity } & Costa et al (2007) & \multirow{9}{*}{$\begin{array}{c}\text { Stimulus to Creative Industries } \\
\text { Stimulus to Creative Industries } \\
\text { Investments in S\&T and stimulus to Creative Industries } \\
\text { Stimulus to Creative Economy } \\
\text { Investments in R\&D, establishment of an academic environment } \\
\text { and transparency of public agencies } \\
\text { Diversity and urban instability as conditions which stimulate urban } \\
\text { creativity } \\
\text { Stimulus to Creative Industries } \\
\text { Stimulus to Creative Industries } \\
\text { Stimulus to Creative Economy }\end{array}$} \\
\hline & Martin et al (2015) & \\
\hline & Evans (2009) & \\
\hline & Waitt and Gibson (2009) & \\
\hline & $\begin{array}{l}\text { Å. Andersson and D. } \\
\text { Andersson (2015) }\end{array}$ & \\
\hline & Hospers and Pen (2008) & \\
\hline & Hall (2000) & \\
\hline & Carter (2013) & \\
\hline & Grodach (2013) & \\
\hline \multirow{6}{*}{ Innovation } & Hospers (2008) & \multirow{6}{*}{$\begin{array}{l}\text { Innovation as social process in cities } \\
\text { Stimulus to innovation and knowledge from public agencies to } \\
\text { firms and population } \\
\text { Science, technology and innovation in urban environment } \\
\text { Science, technology and the establishment of a city branding in } \\
\text { urban environment }\end{array}$} \\
\hline & $\begin{array}{l}\text { Capello, Caragliu and Lenzi } \\
\text { (2012) }\end{array}$ & \\
\hline & Shearmur (2012) & \\
\hline & Marceau (2008) & \\
\hline & Fang et al (2014) & \\
\hline & Inkinen (2015) & \\
\hline
\end{tabular}


The city innovative image is idealized according to the way its citizens, tourists and governments see it as able to attract investment and foster innovation (Hospers 2008; Hicks et al 2001). According to Hospers (2008), this image called branding, it is related to the city ability to attract investments, technology companies, tourists and make possible the qualified human resources to settle in the city. To make it happen, the public sector of the innovative city must act in some directions, namely: (1) to have a transparent decision, favoring innovation activities (Fang et al 2014; Inkinen 2015); (2) to encourage innovation even in times of economic stability and economic growth (Hospers 2008); (3) to involve the community with the growth objectives towards innovation, regardless of the city population density (Hospers 2008).

As complex organizations, the impacts of understanding the entrepreneurial implications, creative and innovative in cities must pass at first by the categorization of these concepts. Table 1 shows the main categories of the cities three development areas, namely entrepreneurship, creativity and innovation.

\section{Methods and Techniques}

Being an exploratory and qualitative research, we have adopted the reflexive methodology for the study (Alvesson and Sköldeberg 2000). The survey has been conducted in five stages. On the first stage has been developed the city model state of the art review of the individual while entrepreneurial agent, and the creative and innovative city notions. Next, we've performed the main elements analysis that make up each one of these notions. On the third stage have been identified the dimensions that make up the model of the city model. On the fourth stage was made the data collection at the level of cities in Brazil. We collected data on design, programs and entrepreneurial actions, creative and innovative in 51 Master Plans (MP) of 52 Brazilian cities, ranked according to their Municipal Human Development Indexes (IDHM) in 2010, prepared by the United Nations Development Programme (UNDP). On the fifth and final stage was held the city model operation illustration, taking into account the City Statute and the cities data collection.

\section{The Entrepreneurial City Model Tool}

The city model term literature review reveals that the word has no meaning and connection to the entrepreneurship field. Also the entrepreneurial review literature, creative and innovative city provides a scientific knowledge platform in this article that enables to anchor the city model transformati ve propositions. In the literature reflection it has been found that creativity and innovation are entrepreneurial behavior characteristics and they are closely linked to the individual sphere. Anchored in this prerogative that the processes of enterprise, create and innovate are resulted from the individual sphere, it appears that the entrepreneurial behavior, creative and innovative develops and expands through the interactions and group dynamics procedures, disseminating in the organization and in all contexts of society, whether at the municipal, state or federal level. Supported on these findings, we have adopted and prefer to work with the term entrepreneurial city model tool, due to of synthesizing, assembling and embracing the creative city notions and innovative city and not creative or innovative city model. As it has been noted, creativity and inno vation are key features of the individual entrepreneur.

The entrepreneurial city model tool (Table 2) which is proposed has as its starting point the work of Taran et al (2015). The entrepreneurial city model tool meets five essential transformative dimensions: value proposition, customers, value configurations, strategic partnerships and revenue model. These aspects contribute to broaden the understanding and understanding the city new concept (entrepreneurial, creative and innovative) that aims to be achieved in the short, medium or long term and provides information to the cities management process (Baglieri, Cinici and Mangematin 2011).

Table 2. The Entrepreneurial City Model Tool

\begin{tabular}{cc}
\hline Dimension & Issue \\
\hline $\begin{array}{c}\text { Value Proposition } \\
\text { Customers }\end{array}$ & $\begin{array}{c}\text { What city conception do we wish to build? } \\
\text { To whom is this city conception? }\end{array}$ \\
$\begin{array}{c}\text { Value Configuration } \\
\text { Strategic Partnerships } \\
\text { Revenue Model }\end{array}$ & $\begin{array}{c}\text { What are the resources and activities which enable the build } \\
\text { of the city conception? }\end{array}$ \\
What partnerships will be held to build this city conception? \\
What revenue structure will be pursue?
\end{tabular}

The entrepreneurial city model tool proposed and its transformative dimensions (Table 2) seek to synthesize, assemble and embrace the notions of entrepreneurial city, creative city and innovative city, from the postulation of five questions that guide the public policies formulation for city management. These issues are related to the way in which decision-makers and public policy makers in the cities seeking: (1) to identify the concept of city design that will be pursued and the image addressed that will be inserted and created in the value proposition; (2) to establish to whom this city design is inserted to the value proposition; (3) to postulate resources (human, 
financial, economic, social and technical) and activities that promote the concept of desired city; (4) to determine the major partnerships that must be performed for the city design construction; (5) to sedimentary the revenues structure that will be implemented in the new city design.

\section{Operationalization of the Entrepreneurial City Model Tool}

The entrepreneurial city model tool (ECM tool) proposed aims to increase the dynamics understanding of the procedural flow in the city context, from the entrepreneurial activity perspective. These process flows dynamics can be expressed in the city, for example, in the planning, implementation and actions monitoring, programs, projects and public policies directed to notions of entrepreneurial city, creative and innovative. The dimensions processing operation that comprise the ECM tool illustrates the understanding of public policies carried out in the city towards an entrepreneurial society. It is wanted, in this article, to illustrate the tool at two levels, namely: (1) Federal, in particular, by the Brazilian Cities Statute Law; (2) Location, i.e., in the city, supported by the Cities Master Plans with the 50 largest Municipal Human Development Index (IDHM) of Brazil.

\subsection{City Statute}

The City Statute (Brazilian Law No. 10,257 of 07/10/2001) is the law that establishes and regulates urban policy and the cities' planning in terms of socioeconomic development in Brazil (Brazil 2001). The Statute lays down the main guidelines by which the policymakers should work towards the Brazilian cities development strategies, for example, Master Plans (MP). The MP is the management plan that posits the city main development guidelines, with its mandatory update every 10 years (Brazil 2001). In a particular way, the City Statute emphasizes that in cities with a population of 20000 inhabitants, is through the MP that ensures citizens the quality of life, social justice and ensuring the development of economic activities in the city (Brazil 2001).

In the analysis of the City Statute was found the lack of entrepreneurial, creative and innovative city notions as drivers of public policies and the cities' planning. Howe ver, even being absent the mention of guidelines linked to entrepreneurship, creativity and inno vation in the Statute, the ECM tool and its dimensions allow foster and broaden the understanding of the main guidelines and strategies to be developed in relation to the dynamics of the cities. This understanding fostered by the ECM tool aims to collaborate with the planning, implementation and monitoring of public policies sedimented in the entrepreneurship paradigm, and to be able to ensure compliance with the guidelines presented in the Statute.

The ECM tool proposed raises the discussion about the building of a design and the city image aligned with the Statute guidelines, while surrounding it with the entrepreneurial dynamic, creative and innovative. On the other hand, it lists the resource identification dynamics (human, financial, economic, social and technical), the creation of partnerships and the establishment of a revenue structure in the city of design construction. Finally, the ECM tool also raises the reflection on the construction beneficiaries of the design proposed city and to whom the city is designed, inserting it into the value proposition.

\subsection{Cities Master Plans}

The cities survey with the 50 largest Municipal Human Development Indexes (IDHM) in 2010 (52 cities), is presented in Table 3. These cities represent more than $30 \%$ of gross domestic product (GDP) in 2013, according with the Brazilian Institute of Geography and Statistics (Brazilian Institute of Geography and Statistics [IBGE], 2013). Preliminary analysis of the data leads us to some conclusions: (1) The Águas de São Pedro town has no Master Plan (MP), depending on which has an estimate population of less than 20000 inhabitants; (2) Of the 52 cities, 28 are not included in their MPs activities or development initiatives related to entrepreneurship and/or creativity and/or innovation. The analyzed cities MPs of six towns (Assis, Rio Claro, São Miguel do Oeste, Botucatu and São José do Rio Preto) entrepreneurial activities have been identified without mentioning innovation activities. In three cities (Ilha Solteira, Jaraguá do Sul, Rio de Janeiro) creative and innovative activities have been identified, not mentioning the entrepreneurial activities. 
Table 3. City with the 50 largest Municipal Human Development Indexes (IDHM) in 2010

\begin{tabular}{|c|c|c|c|c|c|c|c|c|c|c|}
\hline \multirow[t]{2}{*}{ City } & \multirow[t]{2}{*}{ State } & \multirow{2}{*}{$\begin{array}{l}\text { IDHM } \\
(\mathbf{2 0 1 0})\end{array}$} & \multirow{2}{*}{$\begin{array}{l}\text { Population } \\
\text { (2010) }\end{array}$} & \multirow{2}{*}{$\begin{array}{c}\text { Revenue }(\mathbf{R} \$ 1000) \\
(2014)\end{array}$} & \multicolumn{3}{|c|}{ STPs Initiatives } & \multicolumn{3}{|c|}{$\begin{array}{c}\text { Master } \\
\text { Plans }\end{array}$} \\
\hline & & & & & Project & Implementation & Operation & $\mathbf{E}$ & C & I \\
\hline São Caetano do Sul & SP & 0,862 & 149.263 & 4.274 .921 & 0 & 0 & 0 & \multicolumn{3}{|c|}{ NTI } \\
\hline Águas de São Pedro & SP & 0,854 & 2.707 & 92.926 & 0 & 0 & 0 & \multicolumn{3}{|c|}{ NTPD } \\
\hline Florianópolis & SC & 0,847 & 421.240 & 5.140 .297 & 0 & 0 & 2 & $\mathrm{X}$ & & $\mathrm{X}$ \\
\hline Vitória & ES & 0,845 & 327.801 & 6.261 .187 & 0 & 1 & 0 & \multicolumn{3}{|c|}{ NTI } \\
\hline Balneário Camboriú & SC & 0,845 & 108.089 & 1.973 .150 & 0 & 0 & 0 & \multicolumn{3}{|c|}{ NTI } \\
\hline Santos & SP & 0,840 & 419.400 & 7.926 .384 & 0 & 1 & 0 & $\mathrm{X}$ & & $\mathrm{X}$ \\
\hline Niterói & RJ & 0,837 & 487.562 & 7.027 .294 & 0 & 0 & 0 & \multicolumn{3}{|c|}{ NTI } \\
\hline Joaçaba & SC & 0,827 & 27.020 & 444.000 & 0 & 0 & 0 & \multicolumn{3}{|c|}{ NTI } \\
\hline Brasília & DF & 0,824 & 2.570 .160 & 65.516 .179 & 1 & 2 & 0 & $\mathrm{X}$ & $\mathrm{X}$ & $\mathrm{X}$ \\
\hline Curitiba & PR & 0,823 & 1.751 .907 & 23.290 .047 & 0 & 0 & 2 & $\mathrm{X}$ & & \\
\hline Jundiaí & SP & 0,822 & 370.126 & 6.167 .892 & 0 & 0 & 0 & $\mathrm{X}$ & & $\mathrm{X}$ \\
\hline Valinhos & SP & 0,819 & 106.793 & 1.643 .258 & 0 & 0 & 0 & \multicolumn{3}{|c|}{ NTI } \\
\hline Vinhedo & SP & 0,817 & 63.611 & 1.566 .185 & 0 & 0 & 0 & \multicolumn{3}{|c|}{ NTI } \\
\hline Araraquara & SP & 0,815 & 208.662 & Não Informado & 0 & 0 & 0 & $\mathrm{X}$ & & $\mathrm{X}$ \\
\hline Santo André & SP & 0,815 & 676.407 & 7.398 .617 & 1 & 0 & 0 & $\mathrm{X}$ & & $\mathrm{X}$ \\
\hline Santana de Parnaíba & $\mathrm{SP}$ & 0,814 & 108.813 & 2.682 .961 & 0 & 0 & 0 & \multicolumn{3}{|c|}{ NTI } \\
\hline Nova Lima & MG & 0,813 & 80.998 & 2.310 .758 & 0 & 0 & 0 & \multicolumn{3}{|c|}{ NTI } \\
\hline Illha Solteira & SP & 0,812 & 25.064 & 471.689 & 1 & 0 & 0 & & & $\mathrm{X}$ \\
\hline Americana & SP & 0,811 & 210.638 & 2.420 .432 & 0 & 0 & 0 & & NTI & \\
\hline Belo Horizonte & MG & 0,810 & 2.375 .151 & 32.693 .412 & 0 & 0 & 1 & $\mathrm{X}$ & & $\mathrm{X}$ \\
\hline Joinville & $\mathrm{SC}$ & 0,809 & 512.288 & 6.248 .217 & 1 & 0 & 1 & $\mathrm{X}$ & & $\mathrm{X}$ \\
\hline São José & SC & 0,809 & 209.804 & 1.971.324 & 0 & 0 & 0 & & NTI & \\
\hline Maringá & PR & 0,808 & 357.077 & 4.152 .220 & 1 & 0 & 0 & & NTI & \\
\hline $\begin{array}{l}\text { São José dos } \\
\text { Campos }\end{array}$ & SP & 0,807 & 629.921 & 8.817 .953 & 0 & 0 & 2 & $\mathrm{X}$ & & $\mathrm{X}$ \\
\hline Blumenau & $\mathrm{SC}$ & 0,806 & 309.011 & 4.240 .927 & 1 & 0 & 1 & & NTI & \\
\hline Presidente Prudente & SP & 0,806 & 207.610 & 2.171 .777 & 0 & 0 & 0 & & NTI & \\
\hline Rio Fortuna & SC & 0,806 & 4.446 & 81.215 & 0 & 0 & 0 & & NTI & \\
\hline Campinas & SP & 0,805 & 1.080 .113 & 22.280 .062 & 2 & 2 & 1 & $\mathrm{X}$ & & $\mathrm{X}$ \\
\hline Porto Alegre & RS & 0,805 & 1.409 .351 & 19.531 .223 & 1 & 1 & 0 & $\mathrm{X}$ & & \\
\hline São Paulo & SP & 0,805 & 11.253 .503 & 157.745 .044 & 2 & 0 & 0 & $\mathrm{X}$ & & $\mathrm{X}$ \\
\hline Assis & SP & 0,805 & 95.144 & 940.000 & 0 & 0 & 0 & $\mathrm{X}$ & & \\
\hline $\begin{array}{l}\text { São Bernardo do } \\
\text { Campo }\end{array}$ & SP & 0,805 & 765.463 & 13.123 .139 & 0 & 0 & 0 & & NTI & \\
\hline São Carlos & SP & 0,805 & 221.950 & 2.462 .899 & 0 & 1 & 1 & & NTI & \\
\hline Rio Claro & SP & 0,803 & 186.253 & 2.496 .354 & 0 & 0 & 0 & $\mathrm{X}$ & & \\
\hline Jaraguá do Sul & SC & 0,803 & 143.123 & 2.320 .316 & 0 & 0 & 0 & & & $\mathrm{X}$ \\
\hline Rio do Sul & SC & 0,802 & 6.198 & 858.688 & 0 & 0 & 0 & & NTI & \\
\hline $\begin{array}{l}\text { São Miguel do } \\
\text { Oeste }\end{array}$ & $\mathrm{SC}$ & 0,801 & 36.306 & 380.731 & 0 & 0 & 0 & $\mathrm{X}$ & & \\
\hline Bauru & SP & 0,801 & 343.937 & 3.417 .326 & 0 & 0 & 0 & & NTI & \\
\hline Pirassununga & SP & 0,801 & 70.081 & 755.389 & 0 & 0 & 0 & & NTI & \\
\hline Ribeirão Preto & SP & 0,800 & 604.682 & 7.438 .627 & 0 & 1 & 0 & $\mathrm{X}$ & & $\mathrm{X}$ \\
\hline Botucatu & SP & 0,800 & 127.328 & 1.315 .601 & 0 & 1 & 0 & $\mathrm{X}$ & & \\
\hline Taubaté & SP & 0,800 & 278.686 & 3.246 .375 & 0 & 0 & 0 & & NTI & \\
\hline Vila Velha & ES & 0,800 & 414.586 & 3.157 .767 & 0 & 0 & 0 & & NTI & \\
\hline Concórdia & $\mathrm{SC}$ & 0,800 & 68.621 & 832.057 & 0 & 0 & 0 & & NTI & \\
\hline Rio de Janeiro & $\mathrm{RJ}$ & 0,799 & 6.320 .446 & 81.114 .007 & 3 & 0 & 2 & & $\mathrm{X}$ & $\mathrm{X}$ \\
\hline Goiânia & GO & 0,799 & 1.302 .001 & 13.347 .102 & 0 & 1 & 0 & & NTI & \\
\hline Sorocaba & SP & 0,798 & 586.625 & 8.162 .600 & 0 & 0 & 1 & & NTI & \\
\hline Marília & SP & 0,798 & 216.745 & 2.507 .222 & 0 & 0 & 0 & & NTI & \\
\hline Guaratinguetá & SP & 0,798 & 112.072 & 1.024 .763 & 0 & 0 & 0 & & NTI & \\
\hline $\begin{array}{c}\text { São João da Boa } \\
\text { Vista }\end{array}$ & SP & 0,797 & 83.639 & 1.452 .081 & 0 & 0 & 0 & $\mathrm{X}$ & $\mathrm{X}$ & $\mathrm{X}$ \\
\hline $\begin{array}{c}\text { São José do Rio } \\
\text { Preto }\end{array}$ & SP & 0,797 & 408.258 & 4.720 .461 & 0 & 0 & 0 & $\mathrm{X}$ & & \\
\hline Fernandópolis & SP & 0,797 & 64.696 & 600.645 & 0 & 0 & 0 & & NTI & \\
\hline
\end{tabular}

Notes. STP=Science and Technology Parks, NTI=Master Plan does not provide information about development activities linked to entrepreneurship and/or creativity and/or innovation, NPPD=city does not have a Master Plan, $\mathrm{E}=$ development activities linked to entrepreneurship, $\mathrm{C}=$ development activities linked to creativity, $\mathrm{I}=$ development activities linked to innovation. 
The ECM tool synthesizes, assembles and embraces the entrepreneurial activities, creative and innovative in a single conceptual tool as the goal to expand and facilitate the understanding power of the Brazilian cities MPs. This understanding is related to the notion of process flows dynamics that the dimensions of the ECM model offer as an analysis resource of planning, implementation and monitoring of the strategies established in developed countries. First, the tool shows that developed countries may consider as highlight the creative and innovative activities, since they would be carried out in the human sphere and social groups. Second, to mention in the MPs creative and innovative activities without highlighting the entrepreneurial activities, these MPs when analyzed in the light of the tool, they are not properly aligned with the attitude concept and entrepreneurial behavior which are promoted through culture and entrepreneurial education. Third, the MPs analysis were found that the strategies presented include the formulation of public policies for the cities development as it is in the cities that these policies will be implemented. Considering the light of transformative dimensions of the ECM tool, the MPs understanding expands the understanding of how public policy can be held in the city towards the construction of an entrepreneurial society.

In this direction, these activities understanding related to entrepreneurship and innovation mentioned in the developed countries is facilitated by the dimensions proposed regarding to the tool ontological questions. This understanding can be divided into two spheres, namely: (1) cities that do not have de velopment activities related to entrepreneurship and/or creativity and/or innovation in their MPs; (2) cities with development activities related to entrepreneurship and/or creativity and/or innovation in their MPs. In the first level, the ECM tool raises the discussion on the planning of public policies that require alignment and convergence with the terms of the City Statute and the accomplishment of development guidelines, with respect to entrepreneurship, creativity and innovation. The tool is a facilitation for the municipal public policies formulators, to guide the construction of a sedimented city design in the entrepreneurship paradigm.

In the second sphere, the ECM tool allows to establish the correlation between the postulations of development activities presented in the MPs and their effective realization in the cities. The reflections on planning, implementation and monitoring of public policies related to entrepreneurship, creativity and innovation raised by the tool help the municipal public policy formulators on the decision making. Decisions as the city design that will be built and its value proposition, as well as the ability to identify the resources (human, financial, material, social and economic) needed to be taken into account in this building, allows to align the MPs strategies to the search for an entrepreneurial society. In the same way, the inferences accomplished in relation to whom is for the design city for, the major partnerships and revenue structure collaborate with the serviced of development strategies postulated in developed countries, but now under the entrepreneurship paradigm.

\section{Contributions and Practical Implications}

The final results from this present article have several practical implications. We will highlight four groups of practical implications, namely: (1) public management, to the city level, state and country; (2) policy makers; (3) researchers and scholars from universities; (4) human resource professionals. In the city public administration, the ECM tool can constitute on a planning tool, organization, implementation and projects monitoring, programs and policies towards an entrepreneurial design city, state and country. The tool can be taken to stimulate the entrepreneurial culture and a new practice of entrepreneurial public management.

Policy-makers and executives of cities, states and country can promote culture in entrepreneurship and empowerment of people in the adoption of the tool linked to every sphere of public management. The promotion of culture and training will enable to propose amendments to the City Statute and MPs and other legal frameworks aiming at the inclusion of entrepreneurship, creativity and innovation as key drivers of economic and city social development, state and country. Researchers may develop verticalized and further investigation using the results of this research in light of the entrepreneurship field. Undergraduate courses and other courses related to the given public administration, whether in universities or government schools, may introduce new courses or new contents, from the results generated in this research, stimulating new cultures and practices related to the entrepreneurship field. The human resource professionals may introduce the culture of entrepreneurship, creativity and innovation and training courses in these areas, among professionals of companies that provide services to government agencies.

\section{Final Considerations}

It will be necessary to strengthen the following position: (1) the absence of a tool in the national and international literature of entrepreneurship field that gathers, synthesizes and embraces the entrepreneurial city notions, creative city and innovative city in a single analysis model; (2) the absence of a tool leaves the field devoid of instrument that can facilitate the understanding of these dynamics in the formulation of the city public 
policies, to the detriment of the development and economic growth. The proposition about transformative dimensions is embedded in entrepreneurial city model tool, under the entrepreneurial, creativity and innovation level. The developed city model does not offer guarantee of a ready and closed model and will contribute essentially: (1) In the international academic production field of entrepreneurship; (2) In the preparation, implementation and projects monitoring, of programs and policies in cities; (3) In cities development plans.

At the city level, this paper intended to discuss the creation of a research agenda focused on the formulation, implementation, monitoring and e valuation of city models which encourage the development of cities, supported the notions of entrepreneurship, creativity and innovation. The tool contributes to explore, analyze, compare and learn programs, projects, actions and initiatives aimed at the cities development. The action activities and decisions illustration implemented by the cities from the tool may encourage other cities to develop their public policies towards the entrepreneurial, creative and innovative activities.

The results arising from this study provide elements which collaborate in the understanding of the term city model as a tool that assists the planning, implementation and monitoring the city public management towards an entrepreneurial society and a new conception of entrepreneurial city, creative and innovative. New lines of research can be established from this present study and may result in city models constructs to guide the city based on entrepreneurship paradigm, as well as in the development of tools capable of measuring the entrepreneurial dynamics, creative and innovative in the cities.

\section{References}

Abbott, C. (1997). The International City Hypothesis: An Approach to the Recent History of U.S. Cities. Journal of Urban History, 28-52. https://doi.org/10.1177/009614429702400102

Alvesson, M., \& Sköldeberg, K. (2000). Reflexive Methodology: new vistas for qualitative research. Sage.

Andersson, A. E., \& Andersson, D. E. (2015). Creative Cities and the New Global Hierarchy. Applied Spatial Analysis and Policy, 181-198. https://doi.org/10.1007/s12061-015-9141-7

Aschwanden, G. D. P. A., Wullschleger, T., Müller, H., \& Smith, G. (2012). Agent based evaluation of dynamic city models. Automation in Construction, 81-89. http://dx.doi.org/10.1016/j.autcon.2011.07.001

Audretsch, D. B., Belitski, M., \& Desai, S. (2015). Entrepreneurship and economic development in cities. The Annals of Regional Science, 33-60. https://doi.org/10.1007/s00168-015-0685-x

Baglieri, D., Cinici, M. C., \& Mangematin, V. (2012). Rejuvenating Clusters with 'Sleeping Anchors': The Case of Nanoclusters. Technovation, 245-256. http://dx.doi.org/10.1016/j.technovation.2011.09.003

Bakici, T., Almirall, E., \& Wareham, J. (2013). A Smart City Initiative: The Case of Barcelona. Journal of the Knowledge Economy, 135-148. https://doi.org/ 10.1007/s13132-012-0084-9

Brazil. (2001). Lei Número 10.257. Retrieved from http://www.planalto.gov.br/ccivil_03/leis/LEIS_2001/L10257.htm.

Brazilian Institute of Geography and Statistics. (2016). Produto Interno dos Municípios 2010-2013. Retrieved from http://www.ibge.gov.br/home/estatistica/economia/pibmunicipios/2010_2013/default_xls.shtm

Caldas, M., Fachin, R., \& Fischer, T. (org). (1997). Handbook de Estudos Organizacionais: Ação e Análise Organizacionais. Atlas. São Paulo. Vol. 3.

Capello, R., Caragliu, A., \& Lenzi, C. (2012). Is Inno vation in Cities a Matter of Knowledge-Intensive Services? An Empirical Investigation. Innovation - The European Journal of Social Science Research, 151-174. http://dx.doi.org/10.1080/13511610.2012.660326

Cappelle, C., El Najjar, M. E., Charpillet, F., \& Pormorski, D. (2012). Virtual 3D City Model for Navigation in Urban Areas. Journal of Intelligent and Robotic Systems, 377-399. https://doi.org/10.1007/s10846-011-9594-0

Carter, D. (2013). Urban Regeneration, Digital Development Strategies and the Knowledge Economy: Manchester Case Study. Journal of the Knowledge Economy, 169-189. https://doi.org/10.1007/s13132-012-0086-7

Chapin, T. (2002). Beyond the Entrepreneurial City: Municipal Capitalism in San Diego. Journal of Urban Affairs, 565-581. https://doi.org/ 10.1111/1467-9906.00144

Chhetri, P., Han, J. H., Chandra, S., \& Corcoran, J. (2013). Mapping Urban Residential Density Patterns: Compact City Model in Melbourne, Australia. City, Culture and Society, 77-85. 
http://dx.doi.org/10.1016/j.ccs.2013.03.001

Costa, P., Magalhães, M., Vasconcelos, B., \& Sugahara, G. (2007). A discussion on the governance of 'Creative Cities': Some insights for policy action. Norwegian Journal of Geography, 122-132. http://dx.doi.org/10.1080/00291950701553905

Dannestam, T. (2008). Rethinking Local Politics: Towards a Cultural Political Economy of Entrepreneurial Cities. Space and Polity, 353-372. http://dx.doi.org/10.1080/13562570802515267

Dawood, M., Cappelle, C., El Najjar, M. A. E., Khalil, M., El Hassan, B., Pomorski, D., \& Peng, J. (2016). Virtual 3D City Model as a priori Information Source for Vehicle Localization System. Transportation Research Part C: Emerging Technologies, 1-22. http://dx.doi.org/10.1016/j.trc.2015.12.003

Doran, M. A., \& Daniel, S. (2014). Geomatics and Smart City: A Transversal Contribution to the Smart City Development. Information Polity, 57-72. https://doi.org/ 10.3233/IP-140330

Doucet, B. (2013). Variations of the Entrepreneurial City: Goals, roles and visions in Rotterdam's Kop van Zuid and the Glasgow Harbour Megaprojects. International Journal of Urban and Regional Research, 2035-2051. https://doi.org/ 10.1111/j.1468-2427.2012.01182.x

Egger, S. (2006). Determining a Sustainable City Model. Environmental Modelling and Software, 1235-1246. http://dx.doi.org/10.1016/j.envsoft.2005.04.012

Evans, G. (2009). Creative Cities, Creative Spaces and Urban Policy. Urban Studies, 1003-1040. https://doi.org/10.1177/0042098009103853

Fang, C., Ma, H., Wang, Z., \& Li, G. (2014). The sustainable development of innovative cities in China: Comprehensive assessment and future configuration. Journal of Geographical Sciences, 1095-1114.

Filion, L. J. (1993). Visão e Relações: elementos para um metamodelo empreendedor. Revista de Administração de Empresas, 50-61.

Gibb, A. (2002). In pursuit of a new 'enterprise' and 'entrepreneurship' paradigm for learning: creative destruction, new values, new ways of doing things and new combinations of knowledge. International Journal of Management Reviews, 233-269. https://doi.org/ 10.1111/1468-2370.00086

Glaeser, E. L., Rosenthal, S. S., \& Strange, W. C. (2010). Urban Economics and Entrepreneurship. Journal of Urban Economics, 01-14. http://dx.doi.org/10.1016/j.jue.2009.10.005

Grodach, C. (2013). Cultural Economy Planning in Creative Cities: Discourse and Practice. International Journal of Urban and Regional Research, 1747-1765. https://doi.org/10.1111/j.1468-2427.2012.01165.x

Gruen, A., \& Wang, X. (1998). CC-Modeler: A Topology Generator for 3D City Models. ISPRS Journal of Photogrammetry and Remote Sensing, 286-295.

Hackler, D. (2011). Innovation and Entrepreneurship in Cities: Unlock Future Local Economic Growth and Fiscal Capacity. SSRN, 16. http://dx.doi.org/10.2139/ssrn.2015055

Hall, S. P. (2000). Creative Cities and Economic Development. Urban Studies, 639-649. https://doi.org/10.1080/00420980050003946

Hatch, M. J. (1997). Organization Theory: Modern Symbolic and Postmodern Perspectives. Oxford.

Hébert, R. F., \& Link, A. N. (2006). Historical Perspectives on the Entrepreneur. Now Publishers Ink.

Hicks, D., Breitzman, T., Olivastro, D., \& Hamilton, K. (2001). The Changing Composition of Innovative Activity in the US: A Portrait Based on Patent Analysis. Research Policy, 681-703. http://dx.doi.org/10.1016/S0048-7333(00)00147-5

Hisrich, R. D., \& Peters, M. P. (2004). Empreendedorismo. Bookman.

Hospers, G. J. (2008). Governance in innovative cities and the importance of branding. Innovation: management, policy \& practice, 224-234.

Hospers, G. J., \& Pen, C. J. (2008). A View on Creative Cities Beyond the Hype. Creativity and Innovation Management, 259-270. https://doi.org/10.1111/j.1467-8691.2008.00498.x

Inkinen, T. (2015). Reflections on the innovative city: examining three innovative locations in a knowledge bases framework. Journal of Open Innovation: Technology, Market and Complexity, 23. https://doi.org/10.1186/s40852-015-0009-5

Jacobs, A. J. (2016). The City as the Nexus Model: Bridging the State, Market, Societal and Geospatial Contexts. 
Cities, 84-95. http://dx.doi.org/10.1016/j.cities.2015.11.018

Jahnkee, M., Krisp, J. M., \& Fumke, H. (2011). How Many 3D City Models Are There? A Typological Try. The Cartographic Journal, 124-130. http://dx.doi.org/10.1179/1743277411Y.0000000010

Jessop, B., \& Sum, N. L. (2000). An Entrepreneurial City in Action: Hong Kong's Emerging Strategies in and for (Inter)Urban Competition. Urban Studies, 2287-2313. https://doi.org/10.1080/00420980020002814

Lin, M., \& Wu, R. (2015). Production cost heterogeneity in the circular city model. Operations research letters, 401-404. http://dx.doi.org/10.1016/j.orl.2015.04.010

Liu, F., Klimont, Z., Zhang, Q., Cofala, J., Zhao, L., Huo, H., ... Heyes, C. (2013). Integrating Mitigation of Air Pollutants and Greenhouse Gases in Chinese Cities: Development of GAINS-City Model for Beijing. Journal of Cleaner Production, 25-33. http://dx.doi.org/10.1016/j.jclepro.2013.03.024

Marceau, J. (2008). Introduction: Innovation in the city and inno vative cities. Innovation: management, policy \& practice, 136-145. http://dx.doi.org/10.5172/impp.453.10.2-3.136

Martin, R., Florida, R., Pogue, M., \& Mellander, C. (2015). Creativity, Clusters and the Competitive Advantage of Cities. Competitiveness Review, 482-496. http://dx.doi.org/10.1108/CR-07-2015-0069

Mok, K. H. (2005). Fostering Entrepreneurship: Changing Role of Government and Higher Education Governance in Hong Kong. Research Policy, 537-554. http://dx.doi.org/10.1016/j.respol.2005.03.003

Oh, D. S., Phillips, F., Park, S., \& Lee, E. (2016). Inno vation Ecosystems: ACritical Examination. Technovation, 01-06. http://dx.doi.org/10.1016/j.technovation.2016.02.004

Pastén, D., Munhoz, V., Toledo, B., Villalobos, J., Zarama, R., Rogan, J., \& Valdivia, J. A. (2012). Universal Behavior in a Model of City Traffic with Unequal Green/Red Times. Physica A, 5230-5243. http://dx.doi.org/10.1016/j.physa.2012.06.005

Pratt, A. C. (2010). Creative Cities: Tensions within and between social, cultural and economic development: a critical reading of the UK experience. City, Culture and Society, 13-20. http://dx.doi.org/10.1016/j.ccs.2010.04.001

Rahman, M., \& Fatima, N. (2011). Entrepreneurship and Urban Growth: Dimensions and Empirical Models. Journal of Small Business and Enterprise Development, 608-626.

Sahin, C., Alkis, A., Ergun, B., Kulur, S., Batuk, F., \& Kilic, A. (2012). Producing 3D City Model with the Combined Photogrammetric and Laser Scanner Data in the Example of Taksim Cumhuriyet Square. Optics and Lasers in Engineering, 1844-1853. http://dx.doi.org/10.1016/j.optlaseng.2012.05.019

Santos, M. (2004). A Natureza do Espaço: Técnica e Tempo, Razão e Emoção. Editora da Uni versidade de São Paulo - EDUSP.

Schumpeter, J. A. (1934). Theories of Economic Development. Cambridge, MA.

Schumpeter, J. A. (1961). Capitalismo, Socialismo e Democracia. Editora Fundo de Cultura.

Shearmur, R. (2012). Are Cities the Front of Innovation? A Critical Review of the Literature on Cities and Innovation. Cities, S9-S18.

Singhal, S., McGreal, S., \& Berry, J. (2012). An Evaluative Model for City Competitiveness: Application to UK Cities. Land Use Policy, 214-222. http://dx.doi.org/10.1016/j.landusepol.2012.03.018

Smart, P. D., Quinn, J. A., \& Jones, C. B. (2011). City Model Enrichment. ISPRS Journal of Photogrammetry and Remote Sensing, 223-234.

Taran, Y., Nielsen, C., Thomsen, P., Montemari, M., \& Paolone, F. (2015). Business Model Process Configurations: A Mapping Tool For Fostering Innovation. $R \& P$ Management Conference, 11. Retrieved from http://vbn.aau.dk/files/210181877/RnD2015_FullPaper_Business_Model_Process....pdf

Waitt, G., \& Gibson, C. (2009). Creative Small Cities: Rethinking the Creative Economy in Place. Urban Studies, 1223-1246. https://doi.org/ 10.1177/0042098009103862

Yasumoto, S., Jones, A. P., Nakaya, T., \& Yano, K. (2011). The use of a virtual city model for assessing equity in access to views. Computers, Environment and Urban Systems, 464-473. http://dx.doi.org/10.1016/j.compenvurbsys.2011.07.002

Žiūrienè, R., Mešliūtè, R., \& Makutėnienè, D. (2006). Development of 3D City Model Applying Cadastral Information. Geodesy and Cartography, 51-56. http://dx.doi.org/10.1080/13921541.2006.9636693 


\section{Appendix A}

\section{Online Access to Cities Master Plans}

\begin{tabular}{|c|c|}
\hline City & Master Plan \\
\hline Águas de São Pedro & This city does not have a Master Plan \\
\hline Americana & https://leis municipais .com.br/plano-diretor-americana-sp \\
\hline Araraquara & http://www.araraquara.sp.gov.br/pagina/Default.aspx?IDPagina=3973 \\
\hline Assis & http://www.assis.sp.leg.br/arquivos/11177_texto_integral.pdf \\
\hline Balneário Camboriú & http://www.balneariocamboriu.sc.gov.br/sec_planejamento/planos.cfm?codigo=1 \\
\hline Bauru & http://hotsite.bauru.sp.gov.br/planodiretor/lei.aspx \\
\hline Belo Horizonte & http://www.cmbh.mg.gov.br/atividade-legislativa/planejamento-orcamento-publico/plano_diretor \\
\hline Blumenau & http://www.blumenau.sc.gov.br/governo/secretaria-de-planejamento/pagina/revisao-plano-diretor-seplan \\
\hline Brasília & http://www.segeth.df.gov.br/preservacao-e-planejamento-urbano/pdot.html \\
\hline Campinas & http://www.campinas.sp.gov.br/governo/seplama/plano-diretor-2006/ \\
\hline Concórdia & http://www.concordia.sc.gov.br/\#!/tipo/pagina/valor/102 \\
\hline Curitiba & http://www.curitiba.pr.gov.br/planodiretor \\
\hline Fernandópolis & $\begin{array}{c}\text { http://www.fernandopolis.sp.gov.br/uploads/conteudo/a41da96308c902410b9d6c773d8fa 180lc-51--plano } \\
\text {-diretor.pdf }\end{array}$ \\
\hline Florianópolis & $\begin{array}{c}\text { http://www.pmf.sc.gov.br/arquivos/arquivos/pdf/04_02_2014_12.01.39.ae8afdb369c91e 13ca6efcc } 14 b 25 \\
\text { e055.pdf }\end{array}$ \\
\hline Goiânia & http://www.goiania.go.gov.br/shtml/seplam/legis lacao/legis lacao.shtml \\
\hline Guaratinguetá & http://www.splonline.com.br/camaraguaratingueta/Arquivo/Documents/legislacao/image/C232006.pdf \\
\hline Ilha Solteira & http://www.ilhasolteira.sp.gov.br/planodiretor/ \\
\hline Jaraguá do Sul & http://www.jaraguadosul.sc.gov.br/downloads.php?cat=185 \\
\hline Joaçaba & http://www.joacaba.sc.gov.br/portalcidadao/index/detalhes/codMapaItem/12959/codServico/913 \\
\hline Joinville & https://ippuj.joinville.sc.gov.br/arquivo/lista/codigo/9-Plano+Diretor+de+Joinville.ht ml \\
\hline Jundiaí & http://planodiretor.jundiai.sp.gov.br/legislacao/ \\
\hline Marília & $\begin{aligned} \text { http://camar.sp.gov.br/index2.php?pag= } & \text { T1RFPU9HWT 1PRFE9T 1RNPU9UUT1ObUk9T1RBPU9XST1 } \\
& \text { PR1U9T1dZPU9XRT1P }\end{aligned}$ \\
\hline Maringá & http://www2.maringa.pr.gov.br/sistema/arquivos/geo/leis/lc_632_2006_plano_diretor_lei_consolidada.pd \\
\hline Niterói & http://urbanismo.niteroi.rj.gov.br/planodiretor/ \\
\hline Nova Lima & http://www.novalima.mg.gov.br/plano-diretor-revisado/ \\
\hline Pirassununga & http://www.camarapiras sununga.sp.gov.br/ged/lc/2006/69.pdf \\
\hline Porto Alegre & http://www2.portoalegre.rs.gov.br/spm/default.php?p_secao=205 \\
\hline Presidente Prudente & http://www.presidenteprudente.sp.gov.br/site/planejamento_urbano.xhtml \\
\hline Ribeirão Preto & http://www.ribeiraopreto.sp.gov.br/splan/planod/i28planod.php \\
\hline Rio Claro & http://rioclaro.sp.gov.br/pd/index.php \\
\hline Rio de Janeiro & http://www.rio.rj.gov.br/web/smu/plano-diretor1 \\
\hline Rio do Sul & http://riodosul.sc.gov.br/index.php/prefeitura/a-cidade/plano-diretor \\
\hline Rio Fortuna & http://www.camararf.sc.gov.br/anexos/plano-diretor.pdf \\
\hline Rio Preto & http://www.riopreto.sp.gov.br/PortalGOV/do/subportais_Show?c=144 \\
\hline Santana de Parnaíba & http://www.santanadeparnaiba.sp.gov.br/pdm_2005.html \\
\hline $\begin{array}{l}\text { Santo André } \\
\text { Santos }\end{array}$ & $\begin{array}{l}\text { http://www.cms andre.sp.gov.br/index.php?option }=\text { com_content } \& \text { view=article\&id=505\&Itemid=64 } \\
\text { http://www.santos.sp.gov.br/sites/default/files/conteudo/LC\%20821_2013_Plano\%20Diretor.pdf }\end{array}$ \\
\hline São Bernardo do Campo & $\begin{array}{l}\text { http://www.santos.sp.gov.br/sites/default/tiles/conteudo/LC\%20821_2013_Plano\%20Diretor.pdt } \\
\text { http://www.saobernardo.sp.gov.br/plano-diretor }\end{array}$ \\
\hline São Caetano do Sul & http://www.saocaetanodosul.sp.gov.br/pdfs/planos/lei4438planodiretor.pdf \\
\hline São Carlos & http://www.saocarlos.sp.gov.br/index.php/utilidade-publica/plano-diretor.html \\
\hline São João da Boa Vista & http://www.saojoao2050.com.br/ \\
\hline São José & http://www.saojose.sc.gov.br/index.php/sao-jose/plano-diretor-vigente \\
\hline São José do Rio Preto & http://www.riopreto.sp.gov.br/PortalGOV/do/subportais_Show?c=144 \\
\hline São José dos Camps & http://www.sjc.sp.gov.br/secretarias/planejamento_urbano/plano_diretor.aspx \\
\hline São Miguel do Oeste & http://www.saomiguel.sc.gov.br/noticias/5/plano-diretor-municipal \\
\hline São Paulo & $\begin{array}{l}\text { http://www.prefeitura.sp.gov.br/cidade/secretarias/desenvolvimento_urbano/legislacao/plano_diretor/inde } \\
\text { x.php?p=1386 }\end{array}$ \\
\hline Sorocaba & http://www.sorocaba.sp.gov.br/portal/servicos/plano-diretor-de-sorocaba \\
\hline Taubaté & https://leis municipais .com.br/plano-diretor-taubate-sp \\
\hline Valinhos & https://leis municipais .com.br/plano-diretor-valinhos-sp \\
\hline Vila Velha & http://www.vilavelha.es.gov.br/paginas/desenvolvimento-urbano-plano-diretor-municipal-pdm \\
\hline Vinhedo & $\begin{array}{c}\text { http://www.vinhedo.sp.gov.br/meio-ambiente-e-urbanismo/revisao-do-plano-diretor-participativo-de-vinh } \\
\text { edo-2016-2/ }\end{array}$ \\
\hline Vitória & http://sistemas.vitoria.es.gov.br/webleis/Arquivos/2006/L6705.PDF \\
\hline
\end{tabular}

\section{Copyrights}

Copyright for this article is retained by the author(s), with first publication rights granted to the journal.

This is an open-access article distributed under the terms and conditions of the Creative Commons Attribution license (http://creativecommons.org/licenses/by/4.0/). 